\title{
The Distribution of Red Cell Enzyme and Serum Protein Types in a Sample from Iwate, Northern Japan, with the Description of Geographical Cline of Ge Subtypes*
}

\author{
Keiichi Омото \\ Department of Anthropology, Faculty of Science, \\ The University of Tokyo
}

\begin{abstract}
Blood samples from 500 healthy blood donors of Iwate Prefecture, northern Japan, were examined for polymorphism of the following red cell enzyme and serum protein systems by starch-gel electrophoresis and in part by isoelectrofocusing: ACP, PGMl, ESD, GPT, Hp, Tf and subtypes of PGMl and Gc. The distribution of phenotypes and allele frequencies estimated for each system was essentially similar to those reported in other areas of Japan. However, when the data of Gc subtypes thus far reported in Japan excluding Okina'va Islands are compared, statistically significant geographical cline was detected for $\mathrm{GC} * 1 \mathrm{~F}$ and $\mathrm{GC} * 2$ alleles.
\end{abstract}

Keywords Population genetics, Blood genetic markers, Polymorphism, Geographical cline, Japanese.

\section{Introduction}

The geographical difference in gene frequencies among Japanese is an interesting anthropological question. However, aside from the well known case for ABO blood group genes (TANAKA, 1959; NEI and IMAIZUMI, 1966; FUJITA et al., 1978; AOKI and Омото, 1980), few systematic regional differences such as geographical cline have been established in the Japanese main islands for the frequency of polymorphic alleles.
The simplest explanation for the paucity of cline in the polymorphic systems other than $\mathrm{ABO}$ blood group may be that the number of population samples for these systems are still insufficient at present. Since the publication of the gene frequency data of Japanese collected by the Japanese IBP team in 1975 (AKAISHI and KUDO, 1975; IsHIMOTO, 1975; Омото, 1975), the number of polymorphisms examined in Japan, particularly those of enzymes and proteins, may have substantially increased, although the number

Article No. 8522 Received July 11, 1985.

* This study was supported by the grant of Ministry of Education, Science and Culture. The data of this paper were presented at the 69th Meeting of the Japanese Society of Legal Medicine held at Morioka City, 22-24 May, 1985. 
of population samples for these systems are far from sufficient to give a clear picture of the geographical cline such as that obtained for ABO blood group genes. Nevertheless, the geographical cline has been suggested for gene frequencies of red cell GPT (IsHIмото and KUWATA, 1974; UEDA, et al., 1979) and of Gc (YUASA et al., 1983a).

In the course of accumulating new regional data of genetic polymorphism of proteins detected by electrophoresis, a blood sample from Iwate Prefecture, northern Japan, was recently examined for several red cell enzyme and serum protein polymorphisms. The study of genetic markers in Tohoku district appears to be important anthropologically because of its rather peripheral situation in relation to the continental east Asia, the center of postagricultural migration, as well as its geographical closeness to Hokkaido, where the Ainu dwell as the native inhabitant. However, only a few gene frequency data of proteins have been reported from this district. In this paper, the gene frequency data for several protein systems in the Iwate sample will be described together with the finding that the geographical cline is statistically highly significant for the frequencies of both $\mathrm{GC} * 1 \mathrm{~F}$ and $\mathrm{GC} * 2$ alleles in the Japanese main islands.

\section{Material and Methods}

The blood specimens totalling 500 were obtained from healthy blood donors living in the central part of Iwate Prefecture : 130 from Hananomaki City, 140 from Mizusawa City, 120 from Ichinoseki City and 110 from Morioka City. Since these cities are closely located to each other, the samples were combined into a single population sample.

The blood specimens, red cell clots and sera, were sent to Tokyo with dry ice within a few days after collection and stored at $-30^{\circ} \mathrm{C}$ up to about 6 months until tested. The following polymorphic systems were examined by starch-gel electrophoresis with the specific enzyme staining and other staining methods conventionally used (HARRIS and Hopkinson, 1976; Giblet T, 1969). Red cell enzyme systems : acid phosphatase (ACP), phosphoglucomutase 1 (PGM1), esterase D (ESD) and glutamate-pyruvate transaminase (GPT). Serum proteins : Hp and Tf. Isoelectrofocusing in thin-layer polyacrylamide slab was used for subtyping PGMl (KUHNL et al., 1977; MANEYAMA et al., 1978) and Gc, a vitamin-D binding protein in serum (CONSTANS and ViaU, 1977 ; Омото and MiYAKE, 1978). In order to compare rare variant Gc samples, isoelectrofocusing in the Immobiline system (CLEVE et al., 1982) was applied with slight modifications (WATANABE, personal communication).

The search for geographical cline was performed using the allele frequency data obtained in the present study and those previously reported in the Japanese main islands. If two or more data were available in one locality, the data with the largest sample size was used. The data were plotted against the railway distances from Aomori City, and the resulting linear regression was statistically tested for the significance.

\section{Results}

The distribution of phenotypes and allele frequencies for 4 red cell enzyme polymorphic systems examined by starch-gel electrophoresis are shown in table 1.

In ASP, only 3 common phenotypes were found as is usually the case in Japanese. However, 6 samples showed no ACP activity on the gel after electrophoresis and excluded 
Table 1. Distribution of phenotypes and allele frequencies for 4 red cell enzyme systems examined by starch-gel electrophoresis.

\begin{tabular}{|c|c|c|c|c|c|}
\hline System & Phenotype & N. Obs. & N. Exp. & Gene Frequency & S.E. \\
\hline \multirow[t]{5}{*}{$\mathrm{ACP}$} & $\mathrm{A}$ & 18 & 17.70 & $\mathrm{ACP} * \mathrm{~A}: 0.1893$ & 0.0124 \\
\hline & B A & 151 & 151.62 & $\mathrm{ACP} * \mathrm{~B}: 0.8107$ & 0.0124 \\
\hline & $\mathrm{B}$ & 325 & 324.68 & & \\
\hline & Total & 494 & 494.00 & & \\
\hline & & & & \multicolumn{2}{|c|}{$X^{2}=0.0557,1 \mathrm{df}, P>0.80$} \\
\hline \multirow[t]{9}{*}{ PGM1 } & 1 & 284 & 285.77 & PGM1*1: 0.7560 & 0.0136 \\
\hline & $2-1$ & 177 & 174.64 & PGM1*2: 0.2310 & 0.0133 \\
\hline & 2 & 26 & 26.68 & $\mathrm{PGM}^{*} 7: 0.0100$ & 0.0031 \\
\hline & $7-1$ & 8 & 7.56 & PGM1*5: 0.0020 & 0.0014 \\
\hline & $7-2$ & 2 & 2.31 & PGM1*6 $^{*} 0.0010$ & 0.0009 \\
\hline & $5-1$ & 2 & 1.51 & & \\
\hline & $6-1$ & 1 & 0.76 & & \\
\hline & Total & 500 & 499.23 & & \\
\hline & & & & \multicolumn{2}{|c|}{$\mathrm{X}^{2}=0.1274^{*}, 3 \mathrm{df}, \mathrm{P}>0.90$} \\
\hline \multirow[t]{5}{*}{ ESD } & 1 & 207 & 213.86 & ESD*1 $: 0.6540$ & 0.0150 \\
\hline & $2-1$ & 240 & 226.28 & $\mathrm{ESD}^{* 2}: 0.3460$ & 0.0150 \\
\hline & 2 & 53 & 59.86 & & \\
\hline & Total & 500 & 500.00 & & \\
\hline & & & & \multicolumn{2}{|c|}{$\mathrm{X}^{2}=1.8381,1 \mathrm{df}, \mathrm{P}>0.10$} \\
\hline \multirow[t]{5}{*}{ GPT } & 1 & 177 & 171.70 & GPT*1:0.5860 & 0.0155 \\
\hline & $2-1$ & 232 & 242.60 & $\mathrm{GPT}^{*} 2: 0.4140$ & 0.0155 \\
\hline & 2 & 91 & 85.70 & & \\
\hline & Total & 500 & 500.00 & & \\
\hline & & & & \multicolumn{2}{|c|}{$\mathrm{X}^{2}=0.9545,1 \mathrm{df}, \mathrm{P}>0.30$} \\
\hline
\end{tabular}

*) In calculation of chi-square of PGM1 type frequencies, the phenotype 5-1 and 6-1 were excluded.

from the allele frequency calculation. The cause for this unusual, apparently silent phenotype was not knowi. In PGMl, two relatively uncommon phenotypes, PGMl 7-1 and PGMl 7-2, were encountered rather frequently besides the common three phenotypes. The frequency of the allele PGM1*7 was estimated to be approximately 0.01 , indicating the occurrence of this allele at polymorphic frequency. Furthermore, two kinds of rare variants were found and tenta- tively typed as PGMl 6-1 and PGMl 5-1. Judging from the electrophoretic mobility of variant isozymes, it is likely that they are in fact PGMl 6J-1 and PGMl 5J-1, respectively (Омото and HARAdA, 1970; BLAKE and Омото, 1975; SАтон et al., 1976). In ESD, three usual phenotypes only were observed. Also, three common phenotypes and no variants were detected in GPT.

In the PGMl subtype system, a total of 17 phenotypes could be distinguished (Table 2). 
Table 2. Distribution of phenotypes and allele frequencies for the PGM1 subtype examined by isoelectrofocusing.

\begin{tabular}{lrrrr}
\hline Phenotype & N. Obs. & N. Exp. & Allele Frequency & S.E. \\
\hline $1+$ & 218 & 211.90 & PGM1*1+:0.6510 & 0.0151 \\
$1+1-$ & 61 & 68.35 & PGM1*1-:0.1050 & 0.0097 \\
$1-$ & 5 & 5.51 & PGM1*2+:0.1710 & 0.0119 \\
$1+2+$ & 110 & 111.32 & PGM1*2-:0.0600 & 0.0075 \\
$1+2-$ & 35 & 39.06 & PGM1*7+:0.0060 & 0.0024 \\
$1-2+$ & 26 & 17.96 & PGM1*7-:0.0040 & 0.0020 \\
$1-2-$ & 6 & 6.30 & PGM1*6 :0.0010 & 0.0010 \\
$2+$ & 12 & 14.62 & PGM1*5 :0.0020 & 0.0014 \\
$2+2-$ & 10 & 10.26 & & \\
$2-$ & 4 & 1.80 & & \\
$1+7+$ & 3 & 3.91 & & \\
$1+7-$ & 3 & 2.60 & & \\
$1-7+$ & 2 & 0.63 & $\mathrm{X}^{2}=8.231^{*}, 6 \mathrm{df}, \mathrm{P}>0.20$ & \\
$2+7-$ & 1 & 0.68 & & \\
$2-7+$ & 1 & 0.36 & & \\
$1+6$ & 1 & 0.65 & & \\
$1+5$ & 2 & 1.30 & & \\
\hline Total & 500 & 497.21 & & \\
\hline
\end{tabular}

*) Chi-square was calculated for the common phenotypes determined by four common alleles.

Table 3. Distribution of phenotypes and allele frequencies for 2 serum protein systems examined by starch-gel electrophoresis.

\begin{tabular}{|c|c|c|c|c|c|}
\hline System & Phenotype & N. Obs. & N. Exp. & Allele Frequency & S.E. \\
\hline \multirow[t]{5}{*}{$\mathrm{Hp}$} & $1-1$ & 26 & 26.22 & $\mathrm{Hp}^{*} 1: 0.2290$ & 0.0133 \\
\hline & $2-1$ & 177 & 176.56 & $\mathrm{Hp} * 2: 0.7710$ & 0.0133 \\
\hline & $2-2$ & 297 & 297.22 & & \\
\hline & Total & 500 & 500.00 & & \\
\hline & & & & \multicolumn{2}{|c|}{$X^{2}=0.0031,1 d f, P>0.90$} \\
\hline \multirow[t]{5}{*}{$\operatorname{Tf}$} & C & 494 & 494.02 & $\mathrm{Tf}^{*} \mathrm{C}: 0.9940$ & 0.0024 \\
\hline & $\mathrm{CB}$ & 2 & 1.99 & $\mathrm{Tf} * \mathrm{~B}: 0.0020$ & 0.0014 \\
\hline & $\mathrm{CD}$ & 4 & 3.98 & $\mathrm{Tf} * \mathrm{D}: 0.0040$ & 0.0020 \\
\hline & Total & 500 & 499.99 & & \\
\hline & & & & \multicolumn{2}{|c|}{$\mathrm{X}^{2}=0.0002^{*}, \quad 1 \mathrm{df}, \mathrm{P}>0.95$} \\
\hline
\end{tabular}

*) Two variant alleles were combined in the calculation of the chi-square.

Apart from the 10 phenotypes ascribed to 4 common alleles denoted $\mathrm{PGM} 1 * 1+, \mathrm{PGM} 1 * 1-$, $\mathrm{PGM1} * 2+, \quad \mathrm{PGM} 1 * 2-, 5$ phenotypes were distinguishable for heterozygotes of $\mathrm{PGM} 1 * 7$, confirming the existence of two subtypes of this allele, denoted $\mathrm{PGMl} * 7+$ and $\mathrm{PGM} 1 * 7-$ 
Table 4. Distribution of phenotypes and allele frequencies for the Gc subtype examined by isoelectrofocusing.

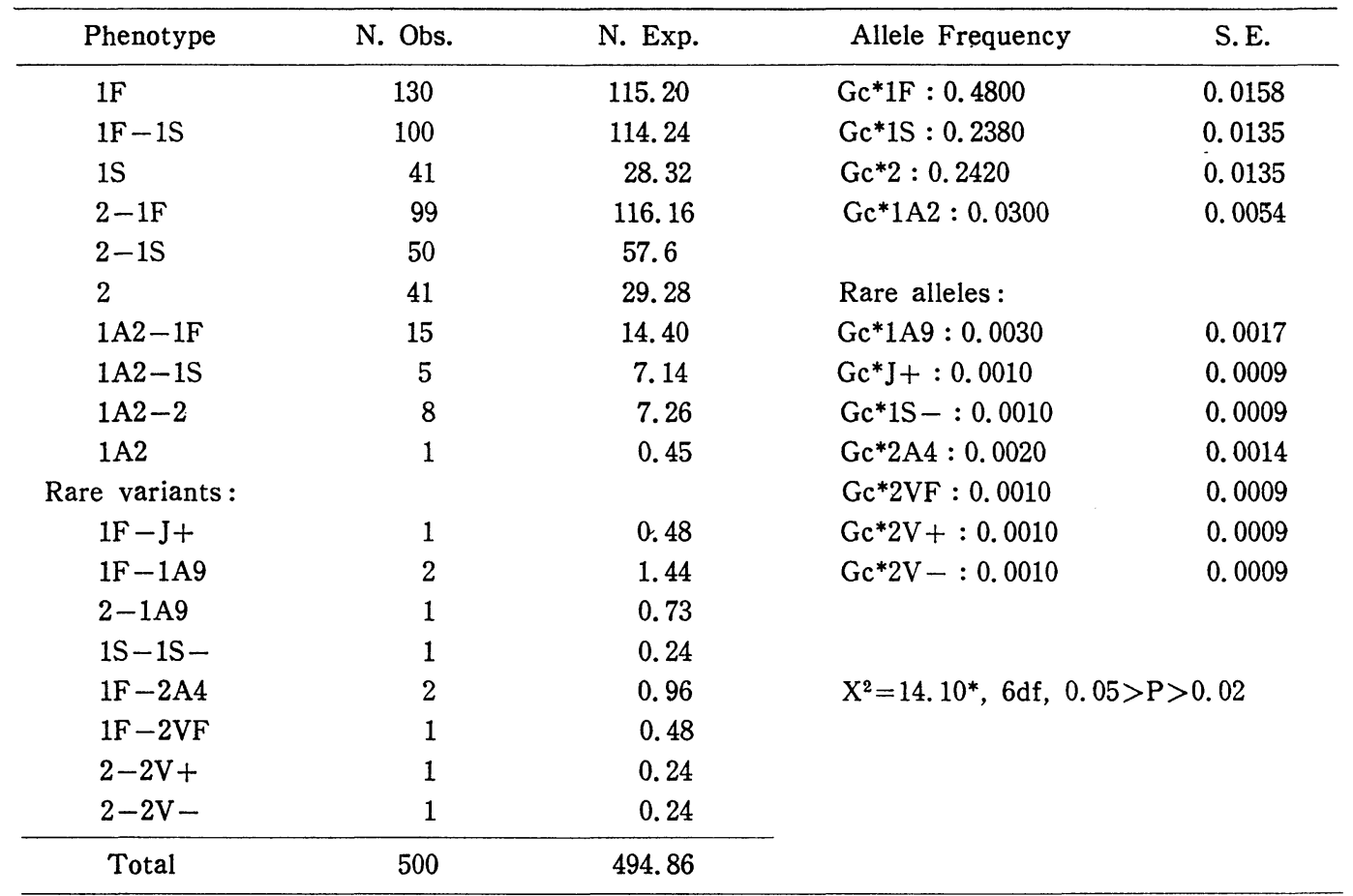

*) Chi-square was calculated on the common phenotypes only.

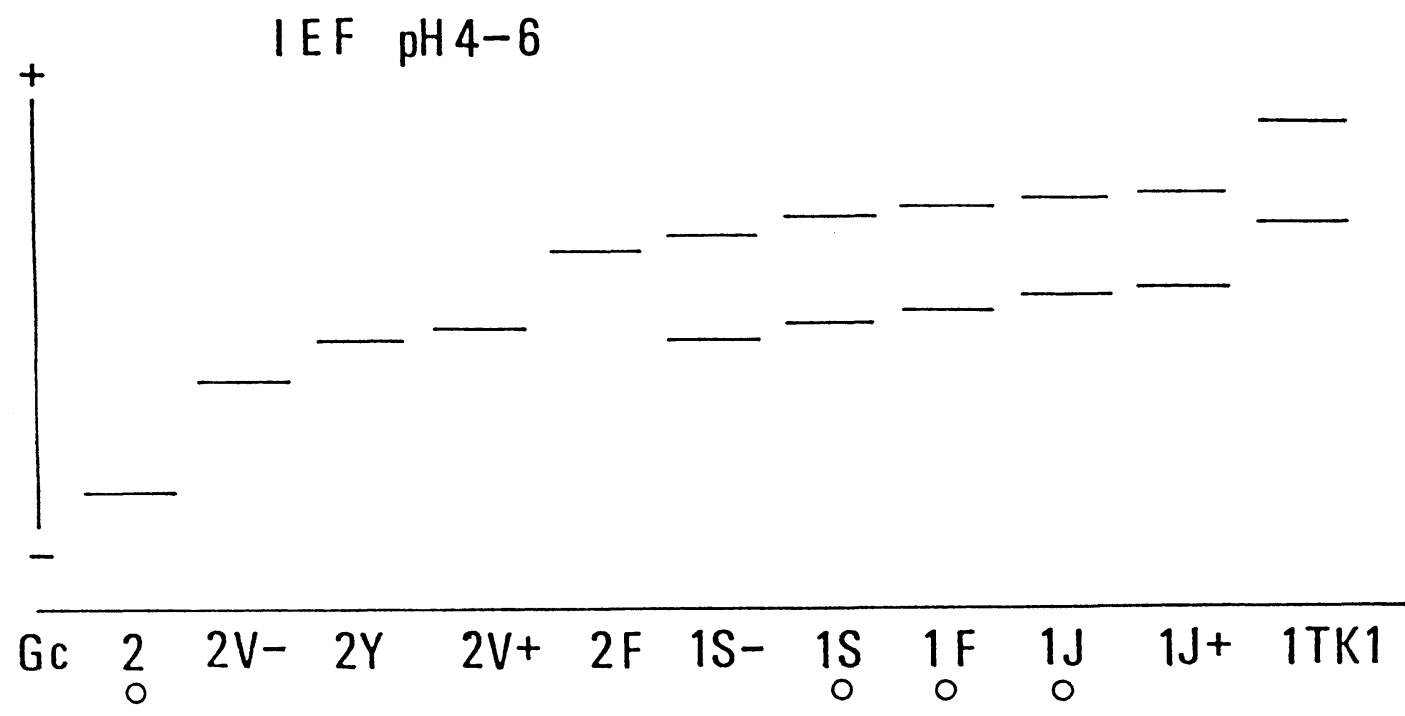

Fig. 1. Diagram showing relative isoelectrofocusing position ( $\mathrm{pH} 4-6)$ of 11 Gc subtypes found in a survey of 500 sera from Iwate Prefecture, northern Japan. The nomenclature used are tentative. Those subtypes occurring in polymorphic frequency are indicated with a circle. 
(TAKAHASHI et al., 1982).

As to the two serum protein systems, $\mathrm{Hp}$ and Tf, conventional starch-gel electrophoretic methods yielded only three common phenotypes in $\mathrm{Hp}$, and a common and two relatively infrequent variant phenotypes in Tf (Table 3). The subtyping of common Tf phenotypes by isoelectrofocusing and the identification of variants are underway.

The result of the Gc subtyping is shown in Table 4 . In addition to 6 phenotypes ascribed to 3 common alleles, Gc*1F, Gc*1S and $\mathrm{Gc} * 2$, at least 12 uncommon phenotypes were observed, indicating the existence of further 8 variant alleles at the Gc locus in northern Japan. Among the rare variants shown in the diagram (Figure 1), four were Gc 2 variants tentatively denoted $2 \mathrm{~V}-, 2 \mathrm{Y}$, $2 \mathrm{~V}+$, and $2 \mathrm{VF}$, while another four were Gc 1 variants, $1 \mathrm{~S}-, 1 \mathrm{~J}, 1 \mathrm{~J}+$ and $1 \mathrm{TK} 1$. According to the international Gc nomenclature, Gc 2Y, Gc $1 \mathrm{~J}$ and $\mathrm{Gc} 1 \mathrm{TK}$ are known as Gc 2A4, Gc 1A2 and Gc 1A9, respectively (Омото and MrYAKE, 1978; Constans et al., 1979; Cleve et al., 1981). The variants were confirmed by isoelectrofocusing in the Immobiline system to be distinct, except Gc $2 \mathrm{~V}+$ which was indistinguishable in this system with Gc 2A4 (WATANABE, personal communication).

\section{Discussion}

Relatively few studies of protein polymorphisms have been reported from Tohoku district, comprising six prefectures, namely, Aomori, Akita, Iwate, Yamagata, Miyagi and Fukushima. Concerning the polymorphic systems dealt with in the present study, Harada and his colleagues reported their results of ACP and PGMl from Aomori, Iwate and Miyagi prefectures (HARADA et al., 1971). A large scale studv of ESD polymorphism was carried out in Miyagi and Yamagata prefectures (SUZUKI et al., 1978). Studies of GPT polymorphism have been published from Aomori, Akita and Miyagi prefectures (KITA et al., 1975; UEDA et al., 1979). Hp types were examined by KuDo (1973) for all the six prefectures. Recently, the result of a survey of red cell enzyme and serum protein polymorphisms in Fukushima Prefecture was published (ABE, 1983).

The frequencies of common alleles and the distribution of rare variants obtained in the present study are essentially similar to those in the previous reports mentioned above. It may be worth pointing out, for example, that two kinds of rare PGM1 variants reported previously from Iwate and Miyagi prefectures (HARADA et al., 1971) may be identical to PGMI 5J and PGMI 6J found in the present study, judging from the electrophoretic pattern. Also, it was confirmed by the present study that the two uncommon isozymes of GPT, GPT 3 and GPT 6 which have thus far been found mainly in the western part of Japan (UEDA et al., 1979), seem to be extremely rare in Tohoku district, if not absent. As to Gc subtypes, at least 6 variants in addition to the common subtypes (Gc 1F, Gc $1 S$ and Gc 2) were found in a survey of 893 sera from Fukushima Prefecture: Gc 1A2, Gc 1A3, Gc 1A8, Gc 1A9, Gc 1C2 and Gc 1C4 (ABE, 1983). Gc 1A2, originally knwon as Gc J (Омото et al., 1972), is widespread in Japanese including the Ainu with a polymorphic frequency, e.g. higher than 0.01 (Омото and MIYAKe, 1978; IshImoto et al., 1979; OMOTO and MiYAKE, 1979 ; MATsumoto et $a l ., 1980)$. Other variants reported by ABE (1983) may also have wide distribution in Japanese and certainly not confined to Tohoku district (SHIBATA, 1983). In the present 


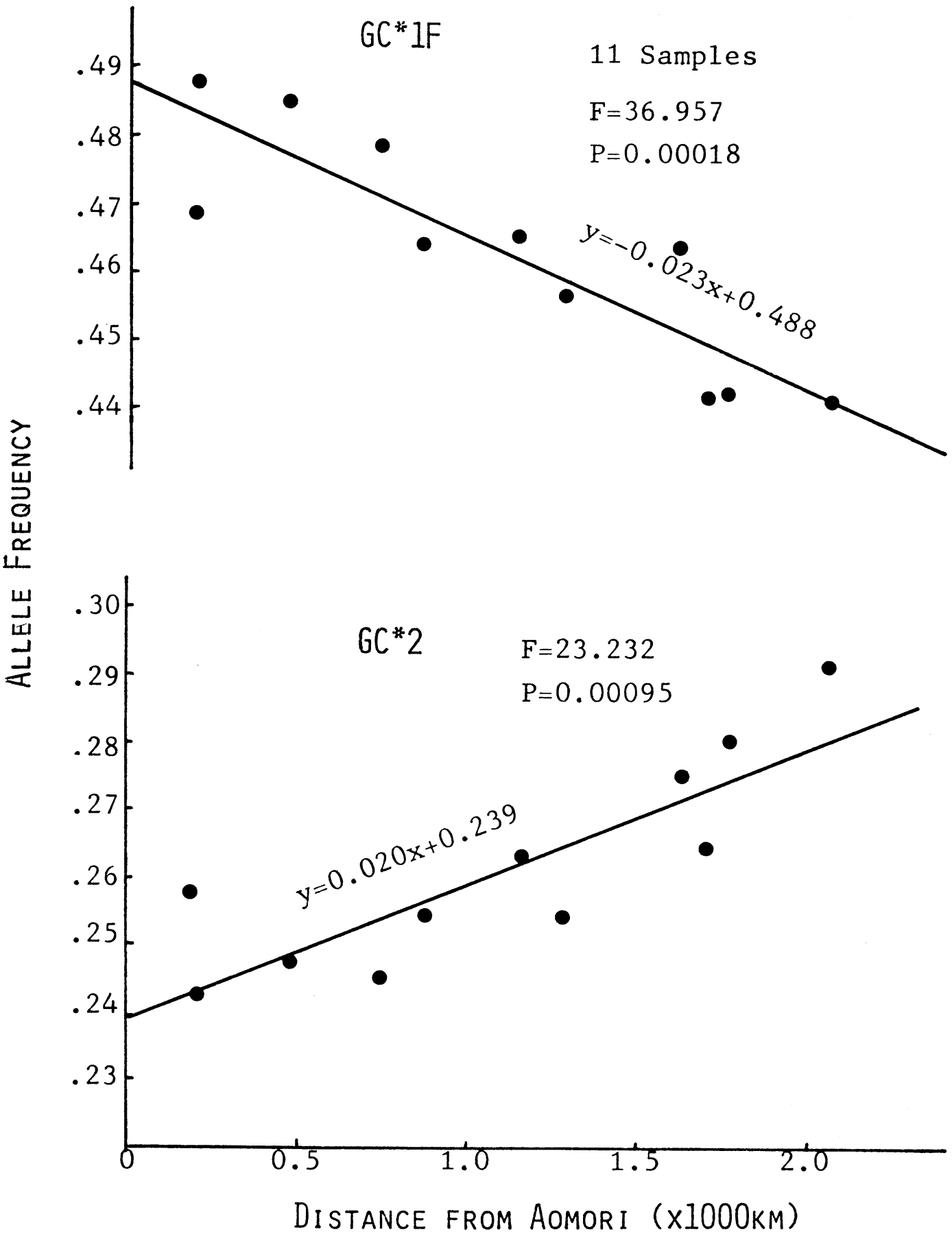

Fig. 2. The regressions between the frequencies of $\mathrm{Gc}^{*} 1 \mathrm{~F}$ and $\mathrm{Gc}^{*} 2$ and the distances from Aomori City, indicating geographical cline. For data see Table 5. 
Table 5. Frequency data of $\mathrm{Gc}$ subtypes $\left(\mathrm{Gc}^{*} 1 \mathrm{~F}\right.$ and $\left.\mathrm{Gc} * 2\right)$ from 11 localities, mostly prefectures, of Japanese Main Islands. Distances are from Aomori City to the prefectural capitols.

\begin{tabular}{lrrrrl}
\hline \multicolumn{1}{c}{ Locality } & Distance* & \multicolumn{1}{c}{$\mathrm{N}$} & $\mathrm{Gc}{ }^{*} \mathrm{~F}$ & $\mathrm{Gc}{ }^{*} 2$ & \multicolumn{1}{c}{ References } \\
\hline Akita & 185.8 & 732 & 0.4693 & 0.2582 & SHINDO \& TAKAHASHI, 1983 \\
Iwate & 203.9 & 500 & 0.4800 & 0.2420 & This study \\
Fukushima & 466.4 & 893 & 0.4854 & 0.2469 & ABE, 1983 \\
Tokyo & 735.6 & 1057 & 0.4782 & 0.2450 & NAKAJIMA \& NAKAZAWA, 1980 \\
Yamanashi & 869.7 & 530 & 0.4642 & 0.2547 & KIDO et al., 1984 \\
Mie & 1168.0 & 510 & 0.4650 & 0.2630 & IsHIMOTO et al., 1979 \\
Osaka & 1292.0 & 342 & 0.4560 & 0.2540 & SHIBATA, 1983 \\
Izumo & 1635.4 & 300 & 0.4600 & 0.2750 & YUASA et al., 1983a \\
Koryo & 1670.9 & 225 & 0.4411 & 0.2645 & YUASA et al., 1983b \\
Yamaguchi & 1775.9 & 400 & 0.4422 & 0.2802 & YUASA et al., 1983a \\
Nagasaki & 2066.0 & 1057 & 0.4410 & 0.2910 & YUASA et al., 1983a \\
\hline
\end{tabular}

*) Railway distance from Aomori City to the prefectural capitol.

study, six rare $\mathrm{Gc}$ variants other than $\mathrm{Gc}$ $1 \mathrm{~A} 2$ were found including several kinds of the Gc 2 variants not recorded by ABE (1983). Further studies are clearly needed to identify the $\mathrm{Gc}$ variants detected in the present study.

When the allele frequencies of 8 polymorphic systems obtained in the present study were compared with those reported previously in Japanese main islands, statistically highly significant geographical cline was found for two of the Gc subtypes. Data of Gc subtypes of 11 localities in the Japanese main islands were available (Table 5). The linear regression equations obtained between allele frequencies $(x)$ and railway distances from Aomori ( $y$ ) were: $y=-0.023 x+0.488$ for $\mathrm{Gc} * 1 \mathrm{~F} ; \mathrm{y}=0.020 \mathrm{x}+0.239$ for $\mathrm{Gc} * 2$ (Figure $2)$. In both cases, the regression was statistically highly significant $(P<0.001)$. This finding confirms the cline for $\mathrm{Gc} * 2$ pointed out recently (YUASA et al., 1983a), and further indicates that the cline is also statistically significant for $\mathrm{Gc} * 1 \mathrm{~F}$ frequency, while it may not be the case for Gc*1S. The Gc*1F frequency tends to be lower, while the $\mathrm{Gc} * 2$ frequency higher, in the western part than in the north-eastern part of Japan.

It should be pointed out that the frequency of $\mathrm{Gc} * 1 \mathrm{~F}$ is known to be high $(0.521-0.579)$ in the Ainu (Омото and Miyake, 1979; MAтsumoto et al., 1980), while that for Chinese may be similar to Japanese (data from Hong Kong : 0.494 ; KWOK and LEwIS, 1981) or much lower than in Japanese (data from Taiwan: 0.397; MATsumoto et al., 1980). It is suggested, therefore, that the Gc cline in Japan may have arisen by gene flow.

A clinal tendency was also noted in $\mathrm{Hp}$ allele frequencies, where data for $\mathrm{Hp} * 1$ were available for 20 population samples from the wide area between Aomori and Kagoshima, the northernmost and the southernmost capitol of Japanese main islands, respectively (Table 6). The regression $y=0.012 x+0.239$ was found to be statistically at the borderline for the significance $(\mathrm{F}=4.419, \mathrm{P} \fallingdotseq 0.05)$ as shown in Figure 3. Although not convincing as in the $\mathrm{Gc}$ cline, it is probable that the $\mathrm{Hp} * 1$ frequency tends to become higher as one goes from northeast to southwest in Japanese main islands. It is interesting that 
Table 6. Data of the $\mathrm{Hp}$ allele frequency from 20 localities, mostly prefectures. Distances are from Aomori City to the prefectural capitols.

\begin{tabular}{|c|c|c|c|c|}
\hline Locality & Distance* & $\mathrm{N}$ & $\mathrm{Hp} * 1$ & Reference \\
\hline Aomori & 0.0 & 2401 & 0.2320 & MURAKAMI \& KITA, 1972* \\
\hline Akita & 185.8 & 1142 & 0.2390 & Kudo, 1973* \\
\hline Iwate & 203.9 & 500 & 0.2290 & This study \\
\hline Yamagata & 397.4 & 991 & 0.2550 & KUDO, 1973* \\
\hline Miyagi & 387.4 & 2000 & 0.2440 & KuDO, 1973* \\
\hline Niigata & 458.8 & 123 & 0.2300 & WATANABE, $1970^{*}$ \\
\hline Fukushima & 466.4 & 980 & 0.2320 & KuDo, $1973^{*}$ \\
\hline Chiba & 774.3 & 2791 & 0.2660 & Isнiмото et al., 1967* \\
\hline Shizuoka & 915.8 & 693 & 0.2510 & SHINODA, $1966^{*}$ \\
\hline Nagoya & 1101.6 & 630 & 0.2930 & OHARA, $1965^{*}$ \\
\hline Gifu & 1131.9 & 1235 & 0.2530 & Онуа et al., 1971* \\
\hline Mie & 1168.0 & 545 & 0.2670 & Isнiмoтo, $1973^{*}$ \\
\hline Nara & 1235.5 & 343 & 0.2540 & YADA \& FUNAKI, 1965* \\
\hline Osaka & 1292.0 & 822 & 0.2750 & Matsumoto, $1964^{*}$ \\
\hline Okayama & 1468.5 & 600 & 0.2600 & ISHIZU \& ANDO, 1972* \\
\hline Hiroshima & 1630.4 & 2073 & 0.2490 & FERRELL et al., 1977 \\
\hline Koryo & 1670.9 & 173 & 0.2183 & YUASA et al., 1983b \\
\hline Fukuoka & 1912.1 & 311 & 0.2570 & YAMAGUCHI, 1961* \\
\hline Nagasaki & 2066.0 & 1374 & 0.2550 & FERRELL et al., 1977 \\
\hline Kagoshima & 2229.2 & 560 & 0.2770 & Ishimoto \& KuWAtA, 1973* \\
\hline
\end{tabular}

*) Railway distance from Aomori City to the prefectural capitol.

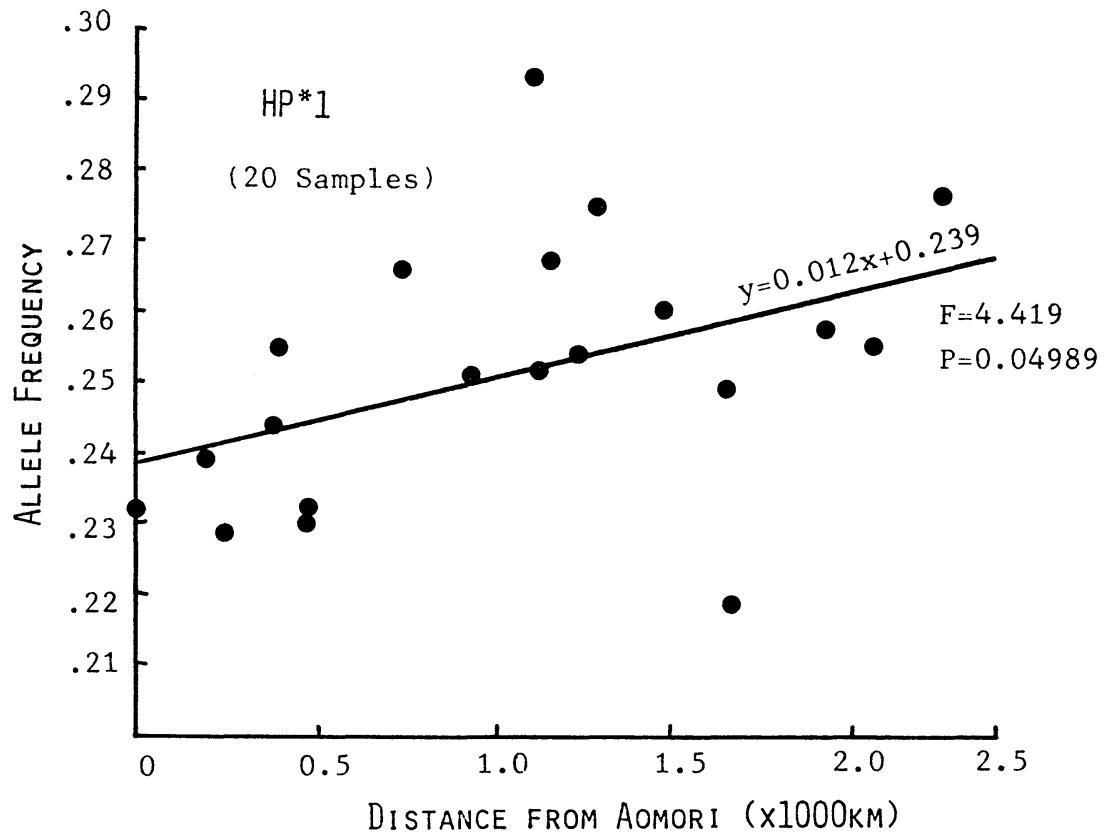

Fig. 3. The regression between the frequencies of $\mathrm{Hp}^{*} 1$ and the distances from Aomori City. For data see Table 6. 
this allele frequency is known to be extremely low in the Ainu, while it tends to be higher in Chinese than in Japanese (Oмото, 1975). Therefore, it is likely that the cline of $\mathrm{Hp}$ allele frequencies, if it really exists, may also be ascribed to gene flow as in the Gc cline.

The findings of geographical cline in the present study are consistent with the idea that there were considerable migration from the continent to the western part of Japan in prehistoric and protohistrric times, affecting to the great extent the genetic composition of the native inhabitants of Japan, who may have been related to the Ainu (Омото, 1973). A migration model was mathematically applied for the $\mathrm{ABO}$ gene frequency cline in Japan (AокI and Омото, 1980).

In the present study, the data from Southwestern (Okinawa) Islands were not taken into consideration, since the distribution of genes in small island populations may be affected by much more complicated factors such as isolation and founder effect than in that of mainland populations. That there may be two independent clines existing in Japan due to the migrations in the past, an east-west cline in Japanese main islands and a north-south cline in South-western Islands, are indicated by such examples as ear-wax types (TERAWAKI, 1975) and red cell GPT (Ishimoto and KuWATA, 1974; Ueda et al., 1979). In both systems, apparent clines were found in South-western Islands but not in the Japanese main islands.

\section{Acknowledgements}

The author wishes to express his gratitudes to Dr. Saburo SHoJI, Iwate Nisseki Blood Center, and Professor Shusaku KATSURA, Iwate Medical University, for giving him opportunity of undertaking this study.
Thanks are due also to Mrs. Yoko ShibAtA, Miss Asami IshIHARA, Mr. Kiyotaka KoIzUMI and Mr. Yoshihisa WATANABE for excellent technical and clerical assistance.

抄録

岩手県の一陚料比ける赤血球酵素・血清虫白型 の分布ならびに Gc 亜型の地理勾配

$$
\text { 尾本恵市 }
$$

岩手目在住の健康な献血者 500 名よりえた血液試料 につき, デンプンゲル電気泳動ならびに一部は等電点 分画により下記の赤血球醅素ならびに血清军白の多型 を検查し心：ACP, PGM 1, ESD, GPT, Hp, Tf, PGM 1 亜型および $G c$ 亜型，各形質に関し推定され た表現型抢よび対立遺云子の分布は，日本の他地域よ り従来報告されていたものと基本的に同様であった。 しかし，Gc 亜型の頻度を沖繩を除く日本各地のデー 夕間で比較したところ， $\mathrm{Gc} * 1 \mathrm{~F}$ および $\mathrm{Gc} * 2$ の頻度 に統計上高度に有意な地理勾配が検出された.

\section{References}

ABE, S., 1983: Genetic polymorphism of red cell enzymes (ACP, EsD, GPT, 6-PGD) and of serum protein $(\mathrm{Gc})$ in Fukushima prefecture. Jpn. J. Human Genet, 28 : 195-200.

AkAishi, S. and T. Kudo, 1975: In Anthropological and Genetic Studies on the Japanese. (ed. by S. Watanabe, S. Kondo \& E. MatsuNAGA, Tokyo, University of Tokyo Press, pp. 109-139.)

Аокі, K. and K. Омото, 1980: An analysis of the $\mathrm{ABO}$ gene frequency cline in Japan: a migration model. J. Anthrop. Soc. Nippon, $88(2)$ : 109-122.

Blake, N.M. and K. Омото, 1975 : Phosphoglucomutase types in the Asian-Pacific area: a critical review including new phenotypes. Ann. Hum. Genet. Lond., 38: 251-373.

Cleve, H., J. Constans, S. Berg, B. Hoste, G. Ishimoto, H. Matsumoto, E. K. Spees and W. WEBER, 1981. Gc revisited: Six further Gcphenotypes delineated by isoelectric focusing and by polyacrylamide gel electrophoresis. Hum Genet, 57 : 312-316. 
Cleve, H., W. Patutschnick, W. Postel, J. WESER and A. Görg, 1982: Analysis of the genetic variants of the human Gc system (VDBP) by isoelectric focusing in immobilized $\mathrm{pH}$ gradients. Electrophoresis, 3.

Constans, J. and M. Viau, 1977 : Group-specific component: Evidence for two subtypes of the $\mathrm{Gc}^{1}$ gene. Science, 198: 1070-1071.

Constans, J., H. Cleve, A. Bennet, R. BouilLON, D. W. CoX, S. P. DAIger, Chr. EhNhOLM, N. FujikI, A. M. Johnson, R. L. KirK, P. KÜHnL, W. Martin, H. Matsumoto, W.R. Mayr, K. Miyake, T. Miyazaki, K. OMOto, H. J. Porck, J. Seger, M. Thymann, D. Tills, M. Toyomasu, H. van Baelen, B. Vavrusa and M. VIAU, 1979: Group-specific component: Report on the first international workshop. Hum Genet, 48: 143-149.

Ferrell, R.E., N. Ueda, C. Satoh, R. J. TANis, J. V. NeEl, H.B. Hamilton, T. Inamizu and K. BABA, 1977: The frequency in Japanese of genetic variants of 22 proteins. Ann. Hum. Genet., Lond. (40) : 407-418.

Fujita, Y., M. TAnimura and K. TAnaka, 1978 : The distribution of the ABO blood groups in Japan. Jpn. J. Human Genet, 23 : 63-109.

GibletT, E. R., 1969: Genetic markers in human blood. Blckwell Scientific Publications, Oxford \& Edinburgh.

Harada, S., S. Akashi, T. Kudo and K. Omoto, 1971: Distribution of phenotypes and gene frequencies of six red cell enzymes in the district of Tohoku, northern part of Japan. J. Anthrop. Soc. Nippon., 79 : 356-366.

HARRIS, H. and D. A. Hopkinson, 1976 : Handbook of enzyme electrophoresis in human genetics. North-Holland, Amsterdam.

Ishimoto, G. and M. KuwatA, 1974: Red cell glutamic-pyruvic transaminase polymorphism in Japanese populations. Jpn. J. Human Genet, $18: 373-377$.

Isнiмото, G., 1975: Red cell enzymes, in : Anthropological and genetic studies on the Japanese, edited by S. WATANABE, S. Kondo and E. Matsunaga, Tokyo, University of Tokyo Press, 1975, pp. 109-139.

Ishimoto, G., M. Kuwata and H. Nakajima, 1979: Group-specific component (Gc) polymorphism in Japanese: An analysis by isoelectric focusing on polyacrylamide gels. Jpn. J. Human Genet, $24: 75-83$.
Kido, A., M. Oya, N. Komatsu and R. Shibata, 1984 : Distribution of Gc subtypes in Yamanashi Prefecture. Jpn. J. Legal Med., 38(4) : 391-396.

Kita, T., T. Murakami and M. Shimizu, 1975 : Discussion on GPT phenotypes (In Japanese). cited in UEDA et al, 1979.

Kudo, T., 1973: unpublished data cited in Омото, 1975.

Kuhnl, P., U. Schmidtmann and W. Spielmann, 1977: Evidence for two additional common alleles at the $\mathrm{PGM}_{1}$ locus (phosphoglucomutaseE. C. : 2.7.5.1.) (A comparison by three different techniques). Hum. Genet., $35: 219-223$.

KwoK, K. Y. Y. and W. H.P. LewIS, 1981: Groupspecific component (Gc) subtypes in the Chinese population of Hong Kong. Hum. Genet., 59 : 72-74.

Maneyama, Y., S. Horai and K. Омотo, 1978 : The distribution of the phosphoglucomutase-1 $\left(\mathrm{PGM}_{1}\right)$ subtypes in Japanese. Jpn. J. Hum. Genet., $23(4)$ : 377-382.

Matsumoto, H., K. Matsui, N. Ishida, K. OHKuRA and Yao-Sheng Teng, 1980: The distribution of Gc subtypes among the Mongoloid populations. Am. J. Phys. Anthrop., 53(4) : 505-508.

Nakajima, H. and E. Nakazawa, 1980: The Gc subtypes in Japanese: Further population and family samples. Jpn. J. Legal. Med., 34: 1-8.

Nakasono, I., M. Iwasaki, M. Ogata, C. Yoshida, T. Yoshitake, K. Narita, T. Fukae and H. SUYAMA, 1983: The distribution of Gc subtypes in the Japanese population of Nagasaki district. Act. Crim. Japon., 49: 27-31.

NeI, M. and Y. Imaizumi, 1966: Genetic structure of human populations. I. Local differentiation of blood group gene frequencies in Japan. Heredity, 21 : 9-36.

Oмото, K. and S. HARAdA, 1970 : Frequencies of polymorphic types of four red cell enzymes in a Central Japanese population. Jpn. J. Human Genet, 14 : 298-305.

Omoto, K., H. Cleve and S. Misawa, 1972: A new variant phenotype of the group-specific component (Gc) found in a Japanese family. Jpn. J. Human Genet, $17: 1-9$.

Омото, K., 1973: The Ainu: a racial isolate? Isr, J. Med. Sci., $9:$ 1285-1290.

Омото, K., 1975: Serum protein groups. In : Anthropological and Genetic Studies on the Japanese. ed. by S. WATANABE, S. KONDO and 
E. Matsunaga, Part II. Distribution of polymorphic traits in the Japanese and neighbouring populations. Univ. of Tokyo Press, pp. 141162, Tokyo.

Омото, K. and K. Miуаке, 1978: The distribution of the group-specific component (Gc) subtypes in Japanese. Jpn. J. Human Genet, 23: 119125.

Омото, K. and K. Miуаке, 1979 : The distribution of subtypes of serum Gc-globulin in Japanese and the neighbouring populations. Jpn. J. Hum. Genet., 24 : 224-225.

Satoh, C., N. Ueda, S. Horai and K. Омотo, 1976: Further studies on phosphoglucomutase1 phenotypes in Japanese. I. Comparison of "slow" variants. Jpn. J. Human Genet, 21 : 85-96.

ShiBAtA, K., 1983: Haptoglobin, group-specific component transferrin and $\alpha_{1}$-antitrypsin subtypes and new variants in Japanese. Jpn. J. Human Genet, 28 : 17-27.

Shindo, S. and K. TAKAhashi, 1983 : Phenotypes of group-specific component and $\alpha_{1}$-antitrypsin in Akita area. Res Pract Forens Med, 26:711.

Suzuki, T., S. Kashimura, K. Umetsu and T. KuDo, 1978: Esterase D phenotypes in Northeastern Japan. Z. Rechtsmedizin, 81: 119-123.

Takahashi, N., J. V. Neel, C. Satoh, J. NishiZAKI and N. MASUNARI, 1982: A phylogeny for the principal alleles of the human phosphoglucommutase-1 locus. Proc. N. A. Sci., $79: 6636-$ 6640 .

TANAKA, T., 1959: A study on the Japanese from the standpoint of the blood groups. (In Japanese with English summary) Jpn. J. Criminol., 25(1) : 37-67.

TERAWAKI, T., 1975: Human genetic studies in South-western Islands. Rinsho to Kenkyu (Clinics and Research), 52: 174-188. (In Japanese)

Ueda, S., K. Омото, K.S. Park and T. Kudo, 1979: Polymorphism of red cell glutamicpyruvic transaminase in Japanese: Gene frequencies in samples from northern Japan. Hum. Hered., 29 : 208-212.

WATANABE, Y., 1984 : personal communication. YuAsA, I., Y. SANEShige and K. OKADA, 1983a : Geographical cline of allele frequency of groupspecific component (Gc) in the Japanese populations: An analysis of data obtained by immunoelectrophoresis. Jpn. J. Human Genet, 28 : 255-261.

YuASA, I., Y. SANEShige and N. OKAMOTO, 1983b: Distribution of $\mathrm{Hp}, \mathrm{Tf}, \mathrm{Gc}$ and $\mathrm{Pi}$ polymorphisms in a Japanese population sample from San-in district. J. Anthrop. Soc. Nippon., 91 : 395-400.

\section{NOTES ADDED IN PROOF}

After the completion of this study the recent paper by YosHIOKA and his colleagues on the distribution of Gc subtypes in northeastern Japan has come under the author's notice. In this paper, data of all the six prefectures of Tohoku District are presented, the total number of samples examined being 4,109. The estimated gene frequencies are as follows :

\begin{tabular}{lccccccc}
\hline & Aomori & Akita & Iwate & Miyagi & Yamagata & Fukushima & Total \\
\hline $\mathrm{N}$ & 593 & 732 & 697 & 647 & 547 & 893 & 4109 \\
\hline $\mathrm{Gc} * 1 \mathrm{~F}$ & 0.4545 & 0.4693 & 0.4699 & 0.4359 & 0.4360 & 0.4854 & 0.4611 \\
$\mathrm{Gc} 1 \mathrm{~S}$ & 0.2470 & 0.2473 & 0.2461 & 0.2666 & 0.2431 & 0.2402 & 0.2480 \\
$\mathrm{Gc}^{*} 2$ & 0.2664 & 0.2582 & 0.2518 & 0.2589 & 0.2761 & 0.2469 & 0.2583 \\
$\mathrm{Gc}{ }^{*} 1 \mathrm{~A} 2$ & 0.0245 & 0.0137 & 0.0194 & 0.0247 & 0.0311 & 0.0196 & 0.0215 \\
others & 0.0076 & 0.0115 & 0.0128 & 0.0139 & 0.0137 & 0.0079 & 0.0111 \\
\hline
\end{tabular}

The regional variation of allele frequencies in this data is considerable, particularly for Gc*1F. Thus, if these figures were added to those used for analysis of geographical cline in the present study (Table 4), the statistical significance for $\mathrm{Gc}^{*} 1 \mathrm{~F}$ cline disappears $(\mathrm{F}=2.943,0.10<\mathrm{P}<0.20)$, while that for $\mathrm{Gc}^{*} 2$ cline remains significant at $1 \%$ level $(\mathrm{F}=7.925,0.01<\mathrm{P}<0.02)$. The disappearance of $\mathrm{Gc}^{*} 1 \mathrm{~F}$ cline seems to be due mainly to the data of Miyagi and Yamagata, in which quite low $\mathrm{Gc}^{*} 1 \mathrm{~F}$ frequencies are observed. As to $\mathrm{Gc}^{*} 2$ frequencies, however, regional variation 
appears to be less marked.

Such an observation seems to indicate the difficulty to establish geographical cline for any gene frequencies when the number of population samples are relatively small. Clearly, much more data are needed to show the Gc cline in Japan to be unequivocal.
YoshiokA, N., S. SHINdo and T. Kudo, 1984 : Distribution of group specific component subtypes among Japanese. Hō-igaku no Jissai to Kenkyu (Research and Practice in Forensic Medicine), 27 : 39-45 (In Japanese with English summary).

\section{昆 本恵市東京大学理学部人類学教室}

T113 東京都文京区本郷 7 丁目 3 番 1 号

Keiichi Омото Department of Anthropology, Faculty of Science,

The University of Tokyo

Hongo 7-3-1, Bunkyo-ku, Tokyo 113, Japan 